\title{
POLICE APPARATUS ROLE IN DETERMINING THE PERPETRATORS' RESPONSIBILITY FOR DESTRUCTION OF GOODS CONDUCTED BY COMMUNITY (IN CASE OF TRAFFIC ACCIDENTS IN KAUR)
}

By:

\author{
Rianto Ade Putra, Antory Royan Adyan, Hamzah Hatrik
}

\begin{abstract}
On Sunday of August $2^{\text {nd }}, 2015$ in Tanjung Harapan highway, Semidang Gumay District of Kaur Regency there has been a vigilantism (Eigenrichting) in the form of destruction and burning of one (1) unit of car that carried out jointly by the community, but until the study was conducted, there has been no follow-up for perpetrators of the destruction and burning of the car, so it raises the question whether the actions taken by community in Tanjung Harapan Village cannot be prosecuted. The purpose of this study was to determine how the role of Police Apparatus in determining the responsibility of perpetrators for destruction and burning of the car. The results showed that the role of Police in determining the responsibility of perpetrators for destruction of goods conducted by community was as the investigators in that case, and must make a report of criminal acts as referred to Article 6 Paragraph (1) and Paragraph (2) of Head of the Indonesian Police (PERKAP) Number 12 of 2009, then these reports provide a basis for investigation in accordance with the provisions laid down in the Criminal Code. Police as investigators may use Article 406 Paragraph (1) and Article 170 of the Criminal Code as a chapter of suspicion in the investigation process against the destruction of goods conducted jointly by the members of the community in Tanjung Harapan Village of Kaur Regency.
\end{abstract}

Keywords: Eigenrichting, Police Apparatus, Destruction of Goods 


\section{A. INTRODUCTION}

\section{Research Background}

Thomas Hobbes calls human by the term Homo Homini Lupus, which means that human nature is individual, selfish and willing to win alone $^{1}$, so that, these conditions will lead to a strong human can arbitrarily against to weak ones. Therefore, the law is expected to create a condition that full regularity in social life, in this case, the law will be tasked to regulate and restrict how the human power to run so as not to harm other people who do not have power.

With the existence of this law, it is expected to create a condition that full regularity in the life of society, but now, in fact, despite the existence of existing laws, there are still events in the community that shows that the law is not / has not been able to be something that can regulate the community. Law that serves to limit the actions of community is often not followed properly. Not infrequently a group of people or even community punish perpetrators of criminal acts/ conduct an act of vigilante (eigenrichting) without following the existing law, the community often takes action without following the rule of law first.

"Vigilante is a
translation of the Dutch
term" Eigenrichting
"which means vigilante,
take a right without
regard to the law,
without government
knowledge and without
the use of government
power".

${ }^{1)}$ Nicolaus Driyakarya, Complete Works of Driyakarya, Essays of the Philosophy of the Thoughtful Thinkers Involved in the Struggle of the People, Jakarta: Gramedia Pustaka Utama: 2006, p. 591. 


\section{This situation could}

occur because of emotional factors of the community against crime that occur in their environment. Law is no longer perceived provide certainty for someone to obtain justice which they are entitled and the law can no longer be trusted as an effective way to regulate life together that can provide a sense of security and peace of the community. The number of criminal acts (crime) which threaten the security of the property to the soul of the community has made community rarely or even ignore the existence of the rule of law.

As an example of the actions of the community to punish perpetrators of criminal acts/vigilante can be seen in the traffic accidents on Sunday,
August $\quad 2^{\text {nd }}, \quad 2015 \quad$ at approximately 16:30 pm on the highway of Tanjung Harapan Village, Semidang Gumay District of Kaur Regency. In that incident, (1) unit minibus had crashed into a motorcyclist wheel 3 (Sunarmin and Arta) that was speeding on the highway in Tanjung Harapan Village, Semidang Gumay District of Kaur Regency, resulting in the 3 -wheel motorcycle riders died. At the time of the incident, by coincidence both were struck and died was the local villagers, the local villagers who did not receive directly destroy and then set fire to a car being driven by the crasher. 3

A person who suspected of committing the 
crime of must goes through the judicial process before they can be convicted if it is found guilty. This is clearly regulated in the provisions of Article 6 paragraph (2) Law Number 48 of 2009 regarding Judicial Power which reads:

"Nobody can be
sentenced unless the
court as proof of legal
instrument under the
law, to get the
confidence
someone who is
considered to be
responsible, have been
guilty of the acts
charged against him."

A person who commits actions considered as a criminal offence cannot be directly imposed criminal sanctions before going through the judicial process. This study will not focus on the actions of community to punish perpetrators of criminal acts in the form of ill-treatment by members of the community against the perpetrators of criminal acts, because in the case of a traffic accident in Kaur, the car driver who rammed successfully saved by police apparatus (Brimob) in Tanjung Harapan Village, so that citizens can not be said to be committed abuses against the driver, but the car of perpetrator impactor destroyed and burned by the society at the location of case and up to this research is conducted, there is no action taken by the Regional Police Chief of Kaur against community who destroyed the car's crasher. Against the act of destruction and burning of a car as in the example case in Kaur that have been previously described, there is already a regulation that regulates the matter that is a provision of 
Article 406 of the Criminal

Code which reads:

(1) The person who with deliberate intent and unlawfully destroys, damages, renders useless or mislays property which wholly or partially belongs to another, shall be punished by a maximum imprisonment of two years and eight months or a maximum fine of four thousand and five hundred rupiahs. ${ }^{4}$

In addition, the actions

of destruction and burning of a car as in Kaur made by many members of the community has also been subject to the provisions of Article 170 of the Criminal Code, which reads:

(1) APersons who with united forces openly commit violence against persons or property shall be punished by a maximum imprisonment of five

4) Team of Vision Yustisia, 3 Main Law Books of Indonesian Penal Code, Criminal Procedure Code, and Civil Code, Jakarta: Visimedia, 2014, p. 91, years and six
months.

(2) The offenders shall be punished:

a. with a maximum imprisonment of seven years, if he intentionally destroys property or of the violence committed by his results in a physical injury;

b. by a maximum imprisonment of nine years, if said violence results in a serious physical injury;

c. by a maximum imprisonment of twelve years, if said violence results in death ${ }^{5}$

In the case of actions of community to punish the perpetrators of the crime/vigilante, it is possible that not everyone who was at the location of case directly against the perpetrators of criminal acts, for example,

5) Solahudin, the draft of Criminal Law, Criminal Procedure, and the Civil Code (Penal Code, Criminal Procedure Code, and KUHPdt) Completed: Law No. 27 of 1999 on the Amendment the Criminal Law Relating to the Crimes against State Security, Jakarta: Transmedia Library, 2008, p. 46. 
there are people who just

provoke with words but do not

take action immediately, it is

necessary to see the provisions

of Article 55 of the Criminal

Code which reads:

"Article 55,

1) As principals of a punishable act shall be punished:

1. those who perpetrate, cause others to perpetrate, or take a direct part in the execution of the act;

2. Those who intentionally

provoke the execution of the act by gifts, promises, abuse of power or of respect, force, threat or deception or by providing an opportunity, means or information.

2) In respect to the provoker only those acts which have been deliberately provoked and their consequences shall be considered $^{6}$

Based on the provisions in Article 55 it can be seen that there is some division as to the actions taken together, so that not only gives the impression of direct involvement as meaning "together" in the article 170 of the Criminal Code but also open space to the other party who did not directly involved. The burning location was in Tanjung Harapan village, so it also will be seen how the village leaders responsibility of Tanjung Harapan village or the head of Tanjung Harapan village against the actions taken by the community that had vandalized goods together. To determine who can be held responsible in the actions of a community 
who destroying goods in case of a traffic accident in Kaur, then it can be asked to Police Apparatus in Kaur area, because, that case was the authority of Police in a jurisdiction of Kaur Regency.

In the example of a case

in Kaur where ordinary villagers of Tanjung Harapan village simultaneously destroyed and burned the car of crasher, the Police Apparatus until now not/did not take action against the perpetrators of the destruction and burning of the car, so this raises the question whether the action taken by the community of Tanjung Harapan cannot be prosecuted or there are other obstacles, it was the primary focus of this study.

The actions of the citizens who burned the car the offender was an act contrary to the law, but the traffic accident on Sunday dated August $2^{\text {nd }}$, 2015 in highway of Tanjung Harapan village of Semidang Gumay Sub District of Kaur Regency where villagers, where the accident occurred, was not accepted the incident immediately destroy the car and then set fire to the car, until present, the car was damaged and burned by villagers of Tanjung Harapan was Minibus 7672 Izuzu Elf No.Pol.E YC in conditions severely damaged and rendered inoperable was in the District Attorney's Office of Kaur (not taken by the owner/returned to the owner). ${ }^{7}$

The minibus Car Izuzu Elf No.Pol.E the YC 7672 was clear evidence that there has

7) Based on the latest information directly from the Servant of State Attorney of Kaur, dated on Saturday of March $23^{\text {rd }}, 2018$. 
been destruction of goods by residents of Tanjung Harapan Village, but the police in the jurisdiction area of Kaur Regency as the law enforcement officers did not take action against to the burning of the car even though there are rules that govern the actions, namely article 406 of the Criminal Code and article 170 of criminal Code, so that this can lead to the assumption that the actions of the community who burns to cars of offender (impactor/Driver) there was no certainty and legal justice for the impactor/driver of the car (which is also a victim of the destruction of goods).

Based on these descriptions, the writer was interested in doing research entitled: "Police Apparatus
Role in Determining the Perpetrators' Responsibility for Destruction of Goods Conducted by Community against Traffic Accident Cases in Kaur".

\section{Identification of Problem}

What is the role of the Police Apparatus in determining the perpetrators' responsibility for the destruction of goods conducted by a community (in the case of a traffic accident in Kaur)?

\section{B. RESEARCH METHODOLOGY}

\section{Types of Research}

Type of research used was empirical legal research, which was a study that focuses its study on law as a real device, a set of actions, and a set of behaviors (so not a set of rules as in the normative approach $)^{8}$. 
In this research, the desired data was an answer that was not available in conventional sources of law as in legal materials but exists in pure empirical field facts. ${ }^{9}$

This research examines the problems of community's action punish the Crime that particularly occurred within the jurisdiction of Kaur Regency of Bengkulu Province, where police as the Apparatus did not take enforcement action for a community who punish the perpetrator crime.

\section{Research Design}

The research design used in this research was descriptive. Descriptive research was a research that aims to describe the nature or characteristics of a

Social Research in the Field of Law, Yogyakarta: Deepublish, 2016, p. 9.

9) Ade Saptomo, Principles of Empirical Nature Legal Research Methodology, Jakarta: Trisakti University, 2009, Page 35. phenomenon, events happening today. ${ }^{10}$ This study was intended to describe the authority of Police Apparatus (As Investigators) in determining the responsibility of Criminal in cases of destruction of cars conducted by a community of Tanjung Harapan Village, Kaur Regency, Bengkulu, as a form of punitive action Actors Crime / Performer Crime caught by the community (vigilante).

\section{Research Location}

The research was conducted in Jurisdiction of Kaur Regency. Selection of location of this research based on the consideration that:

a. In the jurisdiction of Kaur Regency, precisely on Sunday of August $2^{\text {nd }}, 2015$ around 16:30 pm at the

10) Juliansyah Noor, Research Methodology: Thesis, Dissertations, and Scientific Work, Jakarta: Kencana Publishers, 2017, p. 111. 
highway of Tanjung Harapan

Village, sub- District of

Semidang Gumay, there have

been acts of vigilantism

(Eigenrichting) in the form of

destruction and burning of car

action conducted jointly by

the community.

b. The case in Kaur Regency indicates that as if a community has power over the rule of law because it has been destroyed and burned cars of the perpetrators of their villagers irrespective of the rule of law. This can lead to negative views and questions from a community outside the area (who knew about the incident).

\section{Population and Sample}

\section{a. Population}

The population were the number of people or units that have the same characteristics. Another opinion says that population is the entire object or the entire individual or all symptoms or the entire event or the entire unit to be studied. In this research, the scope of population covers the entire of the Police Apparatus in POLRES of KAUR amounting to about 280 people and communities of the all citizens of the incident of Tanjung Harapan Village, Sub-District of Semidang Gumay, Kaur Regency which amounted to about 1170 people.

\section{b. Samples}

Samples were any human or units in the population have an equal opportunity of being selected as an element in a 
sample or a representative of the population to be researched. To determine the sample as respondents in this research was used a purposive technique that determined in advance based on consideration of the ability of respondents. As for the sample in this case were:

1) The car crash destroyed by the community of Tanjung Harapan Village which name is KUPO (KUSPA Bin Junedi).

2) Three police apparatus who were on the location at the time of the destruction and burning of cars by villagers community of Tanjung Harapan Village, consisting of:

- IPDA YANA ROHYANA

(Traffic Police of Kaur).

- BRIGPOL RAKA YOIS, SH (Traffic

Police of Kaur).

- SURYANTO.

(SATBRIMOB of

Kaur)

3) The head of Tanjung Harapan Village (by which time the incidence of destruction and burning of the car by a community of Tanjung Harapan Village was in place and saw immediately the incident).

4) One villager of Tanjung Harapan 
Village who at the

time of the destruction

and car burned by the

Tanjung Harapan

villagers was on the

spot and saw the

incident.

\section{Data Collection Technique}

\section{a. Interview}

An interview was a

form of direct

communication between

researcher and respondent.

Communication took place

in the form of questions and

answer in a face-to-face

relationship so that the

motion and mimic the

respondent was a media

pattern that complements

the verbal words. ${ }^{11}$

\section{b. Secondary Data Collection}

Secondary data was

a data sourced from literature research that data obtained not directly from the first source, but derived from data that have been documented in the form of Legal Materials. The Legal Material consists of Primary Legal Material, Secondary Legal Material, and Tertiary Legal Material. Primary Legal Material includes Legislation, Jurisprudence, Unwritten Legal, then Secondary Legal Material includes legal expert's opinion, Legal books, Legal journals, and Tertiary Legal Material includes Tertiary Legal Dictionary, Encyclopedia. $^{12}$

\section{Data Analysis Method}

12) I Made Pasek Diantha, Legal Research Methodology on Normative Legal Theory In Justification, Jakarta: Prenada Media Group, 2017, p. 192. 
The analytical method used in this research was qualitative juridical the analysis method, in which all the data collected both from the primary data and secondary data, will be processed and analyzed by arranged systematically, classified in patterns and themes, categorized and classified, connected one data with other data, interpretation to understand the meaning of data in a social situation, and interpretation from the perspective of researchers after understanding the overall quality of the data. ${ }^{13}$

\section{RESULTS AND DISCUSSION}

Vigilantism

(Eigenrichting) in the form of destruction and burning of one (1) unit of car that done jointly by the community in Tanjung Harapan Village of Kaur Regency as

13) Ibid, p. 200. previously described was one example of collective violence in the form of anarchy committed by members of the community together which can also be regarded as a violation of the law which could compromise the security and disturbing public order. Responding to this condition, the Police as the starting gate in the criminal justice system has established guidelines in the action PROTAP1/X/2010, signed by the Chief of Police Jend.Pol. Bambang Hendarso Danuri on October $8^{\text {th }}$, 2010.

The scope of the PROTAP includes an overview of forms, traits, actors, anarchy, legal basis of firm action, personnel actions, means of infrastructure, command and control responsibilities and budgets ${ }^{14}$, with the aim to achieve

14) Permanent Procedure of the Chief of Police of the Republic of Indonesia Number: PROTAP / 1 / X / 2010 dated October $8^{\text {th }}, 2010$ On Countermeasures Anarchy, p. 3. 
uniformity of action pattern and not

create doubts for members of Polri

in handling anarchy. Police Action

that was set forth in PROTAP was

forceful measures or other actions

carried out in a responsible manner

in accordance with applicable law

to prevent, inhibit, or stop anarchy

or perpetrators of other crimes that

threaten the safety or harm the

body and soul, property or honor of

decency, in order to embody the

rule of law and order and public

tranquility; The legal basis for

police action is taken which is

regulated in the Criminal Code, namely

1) Article 48: "Not punishable shall be the person who commits an act to which he is compelled by force majors";

2) Article 49 Paragraph (1): " Not punishable shall be the person who commits an act necessitated by the defence of his own or another one's body, chastity or property against direct or immediate threatening unlawful assault ";

3) Article 50: " Not punishable shall be the person who commits an act for the execution of a statutory provision ";

4) Article 51 Paragraph (1): "Not punishable shall be the person who commits an act for the execution of an official order issued by the competent authority

In the case of destruction and burning of cars made jointly by the community in Tanjung Harapan village of Kaur Regency as explained previously, police can conduct investigation on the incident, because the writer argues that the acts committed jointly by these communities have violated the provisions of Article 406 Paragraph (1) and Article 170 of the Criminal Code.

Regarding the procedure or mechanism action of investigation 
that can be done by Police can guidance related provisions which arranged in $K U H A P$ and Regulation of Chief of Police of Republic of Indonesia Number 12 of 2009. In the article 6 Paragraph (1) and Paragraph (2) PERKAP Number 12 of 2009 reads as follows:

(1) The Police report on the existence of a crime shall be made as a basis for conducting an investigation and/or investigation process, consisting of a Model A Police Report, Model B Police Report and Model police Report.

(2) Model A police report made by members of the police were aware of any criminal offence.

Based on Article 2 of PERKAP Number 12 of 2009 , it is stipulated that the Police acknowledging the existence of a criminal offence may make Amodel reports so that these reports can provide a basis for the process of investigating a crime. In cases of vandalism and the burning car community in Tanjung Harapan village of Kaur Regency, there were many polices who witnessed the act so that the writer argues that despite the absence of reports from those who feel aggrieved, Police in Jurisdiction of Kaur Regency may conduct the investigation process based on the A-model report as the foundation made by the Police who witnessed the incident of destruction and burning of car by community in Tanjung Harapan Village of Kaur Regency.

\section{CLOSING}

\section{Conclusion}

Role of the Police Apparatus in determining the perpetrator's responsibility for destruction of goods conducted by community (in traffic 
accident case in Kaur) is very important. Whether or not processing an anarchy action in the form of destruction of goods conducted by the community is determined by the role of the Police as an investigator of criminal act. To make this happen, the Police must first make a report of the criminal acts as referred to in Article 6 Paragraph (1) and Paragraph (2) of PERKAP Number 12 of 2009 , then these reports provide a basis for investigation in accordance with the provisions set forth in the Criminal Procedure Code.

\section{Suggestion}

With the case of vigilantism (Eigenrichting) in the form of destruction and burning of one (1) unit of the car that carried out jointly by the community in Tanjung $\begin{array}{ccc}\text { Harapan } & \text { Village of Kaur } \\ \text { Regency } & \text { as } & \text { previously }\end{array}$ described, it is expected that the Police Apparatus conduct routine counseling about law awareness to Kaur community, especially villages or places where there have been a background of vigilante/mass rampage/anarchy there.

In dealing with vigilante actions (Eigenrichting) that occur within the community, it is expected that Police Apparatus as one component of the criminal justice system in Indonesia to maximize the duties and authorities possessed by the Police especially against the act of destruction of goods carried out jointly by community, because there are already provisions as regulated in Article 6 Paragraph (1) and Paragraph (2) of PERKAP 
Number 12 of 2009, as the legal

basis for the Police to follow up

the act of destruction of goods

carried out jointly by

citizens.because the existing

provisions inArticle 6

Paragraph (1) and Paragraph (2)

the Regulation No. 12 In 2009,

as the legal basis for the police

to follow up act of destruction

of goods conducted jointly by

the community.

\section{REFERENCES}

Ade Saptomo, Principles of Empirical Nature Legal Research Methodology, Jakarta: Trisakti University, 2009.

Juliansyah Noor, Research Methodology:

Thesis, Dissertations, and Scientific

Work, Jakarta: Kencana Publishers, 2017.

I Made Pasek Diantha, Legal Research Methodology on Normative Legal Theory In Justification, Jakarta: Prenada Media Group, 2017.

Moeljatno, the draft Penal Code, Jakarta: Bumi Aksara, 2016.
Nicolaus Driyakarya, Complete Works of Driyakarya, Essays of the Philosophy of the Thoughtful Thinkers Involved in the Struggle of the People, Jakarta: Gramedia Pustaka Utama: 2006.

Rachmad Baro, Non-Doctrinal Legal Research Methods and Techniques Trend Use of Social Research in the Field of Law, Yogyakarta: Deepublish, 2016.

Solahudin, the draft of Criminal Law, Criminal Procedure, and the Civil Code (Penal Code, Criminal Procedure Code, and KUHPdt) Completed: Law No. 27 of 1999 on the Amendment the Criminal Law Relating to the Crimes against State Security, Jakarta: Transmedia Library, 2008.

States Nyoman Putra Jaya, aspects of criminal law against anarchy and vigilantism in the community, Regional Seminar of Police in Pekalongan on August 22 $2^{\text {nd }}, 2000$, p. 1.

Team of Vision Yustisia, 3 Main Law Books of Indonesian Penal Code, Criminal Procedure Code, and Civil Code, Jakarta: Visimedia, 2014, p. 91,

W. Gulo, Research Methodology, Jakarta: Grasindo, 2002, p. 119.

Permanent Procedure of the Chief of Police of the Republic of Indonesia Number: PROTAP / 1 / X / 2010 dated October $8^{\text {th }}, 2010 \quad$ On Countermeasures Anarchy. 